\title{
Analisis Nilai Karakter Dalam Pembelajaran Tematik Tema Cita-Citaku
}

\author{
Fifa Ariyanti ${ }^{1}$, Rustopo ${ }^{2}$, Anggun Dwi Setya Putri ${ }^{3}$ \\ 1,2,3 Pendidikan Guru Sekolah Dasar, Fakultas IImu Pendidikan \\ Universitas PGRI Semarang \\ e-mail: fifaari977@gmail.com
}

\begin{abstract}
Abstrak
Penelitian ini bertujuan untuk menganalisis nilai karakter dalam kegiatan pembelajaran tematik tema cita-citaku pada siswa kelas IV SD Negeri Lamper Tengah 02 Semarang. Jenis penelitian ini adalah kualitatif dengan menggunakan pendekatan deskriptif kualitatif. Sumber data dalam penelitian ini adalah kepala sekolah, guru kelas dan siswa kelas IV SD Negeri Lamper Tengah 02 Semarang. Teknik pengumpulan data yang digunakan dalam penelitian ini yaitu observasi, wawancara dan dokumentasi. Dalam pengecekan keabsahan data, penelitian ini melakukan uji kredibilitas yaitu peningkatan ketekunan, triangulasi, dan menggunakan bahan referensi. Teknik analisis data dalam penelitian ini terdiri dari kegiatan pengumpulan data, reduksi data, penyajian data, dan verifikasi atau menarik kesimpulan. Berdasarkan hasil penelitian dan pembahasan yang telah diuraikan maka dapat ditarik kesimpulan bahwa nilai karakter dalam kegiatan pembelajaran tematik tema Cita-Citaku subtema Giat Berusaha Meraih Cita-Cita pada siswa kelas IV SD Negeri Lamper Tengah 02 Semarang terdapat 14 nilai karakter yang ditemukan yaitu Religius, Jujur, Toleransi, Disiplin, Kerja Keras, Kreatif, Mandiri, Semangat Kebangsaan, Cinta Tanah Air, Bersahabat/Komunikatif, Cinta Damai, Peduli Lingkungan, Peduli Sosial, dan Tanggung Jawab. Sedangkan nilai karakter yang tidak ditemukan adalah Demokratis, Rasa Ingin Tahu, Menghargai Prestasi, dan Gemar Membaca. Nilai karakter yang diteliti terdiri dari 18 nilai karakter dalam pengembangan pendidikan budaya dan karakter bangsa oleh kemendikbud.
\end{abstract}

Kata Kunci : Nilai karakter, aktivitas belajar, tematik

\begin{abstract}
This study aims to analyze the character values in thematic learning activities the theme of my ideals in class IV of Lamper Tengah State Elementary School 02 Semarang. This type of research is qualitative using a qualitative descriptive approach. The data sources in this study were principals, class teachers and fourth grade students of Lamper Tengah State Elementary School 02 Semarang. Data collection techniques used in this study were observation, interviews and documentation. In checking the validity of the data, this study conducted a credibility test, namely increasing perseverance, triangulation, and using reference materials. Data analysis techniques in this study consisted of data collection activities, data reduction, data presentation, and verification or drawing conclusions. Based on the results of the research and discussion that has been described, it can be concluded that the character values in the thematic learning activities the theme of my ideals of the substantial substance Trying to Achieve Ideals in Class IV of Lamper Tengah State Elementary School 02 Semarang there are 14 character values found namely Religious, Honest, Tolerance, Discipline, Hard Work, Creative, Independent, Nationalism, Love of the Motherland, Friendly / Communicative, Love of Peace, Care for the Environment, Social Care, and Responsibility. While the value of characters not found is Democratic, Curiosity, Respect for Achievement, and Reading Joy. The character values studied consisted of 18 character values in the development of cultural and national character education by the Ministry of Education and Culture.
\end{abstract}

Keywords: Character Value, Learning Activity, Thematic 


\section{Pendahuluan}

Pendidikan adalah pengaruh lingkungan atas individu untuk menghasilkan perubahanperubahan yang tetap (permanen) di dalam kebiasaan-kebiasaan tingkah lakunya, pikirannya, dan sikapnya (Thompson dalam Soegeng, 2018: 64). Menurut Undang-Undang Republik Indonesia Nomor 20 Tahun 2003 tentang Sistem Pendidikan Nasional "Pendidikan adalah usaha sadar dan terencana untuk mewujudkan suasana belajar dan proses pembelajaran agar peserta didik secara aktif mengembangkan potensi dirinya untuk memiliki kekuatan spiritual keagamaan, pengendalian diri, kepribadian, kecerdasan, akhlak mulia, serta ketrampilan yang diperlukan dirinya, masyarakat, bangsa dan Negara" (Soegeng, 2018: 65). Berdasarkan pendapat di atas dapat disimpulkan bahwa pendidikan adalah usaha mewujudkan pembelajaran aktif kepada peserta didik melalui kebiasaan tingkah laku, pikiran, dan sikapnya untuk menghasilkan perubahan menjadi manusia yang berkarakter.

Pendidikan lebih dari sekedar pengajaran, yang dapat dikatakan sebagai suatu proses transfer ilmu, transformasi nilai, dan pembentukan kepribadian dengan segala aspek yang dicakupnya. Dengan demikian pengajaran lebih berorientasi pada pembentukan spesialis atau bidangbidang tertentu, oleh karena itu perhatian dan minatnya lebih bersifat teknis. Pendidikan merupakan suatu proses yang diperlukan untuk mendapatkan keseimbangan dan kesempurnaan dalam perkembangan individu maupun masyarakat. Penekanan pendidikan dibanding dengan pengajaran terletak pada pembentukan kesadaran dan kepribadian individu atau masyarakat di samping transfer ilmu dan keahlian. Dengan proses semacam ini suatu bangsa atau negara dapat mewariskan nilai-nilai keagamaan, kebudayaan, pemikiran dan keahlian kepada generasi berikutnya, sehingga mereka betul-betul siap menyongsong masa depan kehidupan bangsa dan negara yang lebih cerah. Pendidikan juga merupakan sebuah aktifitas yang memiliki maksud atau tujuan tertentu yang diarahkan untuk mengembangkan potensi yang dimiliki manusia baik sebagai manusia ataupun sebagai masyarakat dengan sepenuhnya. Pendidikan dalam bahasa Yunani berasal dari kata padegogik yaitu ilmu menuntun anak.Orang Romawi melihat pendidikan sebagai educare, yaitu mengeluarkan dan menuntun, tindakan merealisasikan potensi anak yang dibawa waktu dilahirkan di dunia. Bangsa Jerman melihat pendidikan sebagai Erziehung yang setara dengan educare, yakni: membangkitkan kekuatan terpendam atau mengaktifkan kekuatan atau potensi anak. Dalam bahasa Jawa, pendidikan berarti panggulawentah (pengolahan), mengolah, mengubah kejiwaan, mematangkan perasaan, pikiran, kemauan dan watak, mengubah kepribadian sang anak (Nurkholis ,2013).

Berbicara mengenai pendidikan karakter tidak jauh berbeda dengan pembelajaran karakter. Pendidikan karakter menjadi sangat populer di zaman sekarang karena dalam kurikulum 2013 telah diterapkannya Penguatan Pendidikan Karakter (PPK). Lickona dalam Yaumi (2014: 7) menyatakan bahwa "character as knowing the good, desiring the good, and doing the good (mengetahui kebaikan, menginginkan kebaikan, dan melakukan segala sesuatu yang baik)". Penanaman karakter dalam diri anak dapat dikembangkan salah satunya melalui pendidikan pada anak usia tingkat sekolah dasar. Hal ini menjadi tugas seorang pendidik untuk bertanggung jawab menanamkan keyakinan yang kuat untuk mencegah terjadinya pengaruh negatif dari lingkungan masyarakat.

Manusia berkembang secara terus-menerus melalui tindakannya. Seseorang dianggap baik atau tidak baik dilihat dari tindakannya. Manusia yang memiliki tindakan baik berarti memiliki karakter yang baik, sebaliknya manusia yang memiliki tindakan tidak baik berarti memiliki karakter yang tidak baik. Sebagaimana Parwez dalam Yaumi (2014: 7) menyatakan bahwa karakter adalah sikap manusia terhadap lingkungannya yang diekspresikan dalam tindakan. Tindakan tersebut tumbuh melalui nilai-nilai luhur yang baik. Nilai-nilai luhur tersebut antara lain: kejujuran, kemandirian, sopan santun, kemuliaan sosial, kecerdasan berpikir termasuk kepenasaran akan intelektual, dan berpikir logis (Zubaedi, 2011: 17).

Pendidikan karakter di Indonesia memang sudah dijalankan sejak dulu, namun kenyataannya pendidikan karakter khususnya pada anak belum berjalan secara maksimal. Masalahnya adalah banyak terjadi perilaku menyimpang seperti tawuran antar pelajar dan kekerasan di sekolah. Misalnya tawuran yang terjadi di kota Semarang. Tawuran tersebut membuat satu siswa dari SMK swasta di kota Salatiga mengalami luka dan harus menjalani perawatan di RS Hermina Banyumanik. Kapolsek Banyumanik Kompol Retno Yuli membenarkan adanya peristiwa tawuran tersebut (Tribunjateng.com, 28 Febuari 2018). Hal ini harus disadari bahwa pendidikan karakter pada anak belum berjalan dengan baik dan harus diperbaiki agar tidak semakin lemah. Kegiatan pembelajaran tematik dalam kurikulum 2013 
pada tingkat sekolah dasar merupakan salah satu upaya untuk menanamkan karakter siswa. Pembelajaran tematik yaitu kegiatan mempelajari semua mata pelajaran dengan menggunakan tema-tema kehidupan yang dialami siswa pada kegiatan sehari-hari. Melalui pembelajaran tematik maka guru berperan penting untuk menanamkan nilai-nilai karakter kepada siswa.

Pendidikan karakter bertujuan agar peserta didik sebagai penerus bangsa mempunyai akhak dan moral yang baik, untuk menciptakan kehiupan berbangsan yang adil, aman dan makmur. Tujuan Pendidikan dalam UndangUndang Nomor 20 tahun 2003 tentang Sistem Pendidikan Nasional yang menyebutkan bahwa "Pendidikan nasional berfungsi mengembangkan kemampuan dan membentuk watak serta peradaban bangsa yang bermartabat dalam rangka mencerdaskan kehidupan bangsa, bertujuan untuk berkembangnya potensi peserta didik agar menjadi manusia yang beriman dan bertaqwa kepada Tuhan Yang Maha Esa, berakhlak mulia, sehat, berilmu, cakap, kreatif, mandiri dan menjadi warga negara yang demokratis serta bertanggung jawab (Palupi ,2018).

Berdasarkan hasil wawancara dengan bapak Adri Joko Suyanto, BA. pada tanggal 11 Desember 2018 selaku guru kelas IV di SD Negeri Lamper Tengah 02 mengatakan bahwa penerapan pendidikan karakter pada saat proses pembelajaran berlangsung sangat sulit karena siswa kurang perhatian oleh kedua orang tuanya. Persoalannya adalah banyak siswa khususnya siswa kelas IV yang tinggal dengan neneknya, bukan dengan orang tuanya. Mayoritas orang tua siswa kelas IV merantau di luar kota. Hal ini sangat mempengaruhi pendidikan karakter yang terjadi pada anak tersebut. Maka dari itu, peneliti ingin melakukan penelitian mengenai nilai karakter yang diterapkan melalui pembelajaran tematik tema CitaCitaku pada siswa kelas IV SD Negeri Lamper Tengah 02 Semarang. Dengan adanya pendidikan karakter dalam kegiatan pembelajaran maka akan membentuk siswa yang bermoral, beretika, dan berkarakter.

Pendidikan karakter merupakan salah satu upaya mendasar dalam menciptakan situasi belajar yang memenuhi kebutuhan pengembangan diri siswa pada interaksi belajar yang dirancang guna membentuk siswa berkarakter. Meskipun pembentukan dan pengembangan karakter dapat dilakukan di rumah melalui bimbingan orang tua dan lingkungan sekitar. Namun, sekolah juga memiliki peran penting dalam pembentukan karakter siswa (Suyadi, 2013: 3). Dengan harapan, bahwasannya melalui pendidikan karakter akan menjadikan siswa sebagai sosok yang bertaqwa kepada Tuhan Yang Maha Esa, memiliki keimanan yang kuat sehingga melahirkan pribadi yang berbudi luhur, toleran terhadap sesama, memiliki motivasi juang dan mempu bekerja keras, berprestasi dan disiplin, sikap menghargai orang lain dan demokratis, bertanggungjawab, kreatif dan mandiri (Majid, 2011: 11). Tidak dapat dipungkiri, pendidikan karakter yang mulai ditanamkan melalui proses pembelajaran di sekolah memiliki andil yang sangat besar dan esensial sebagai bagian dalam proses pembentukan akhlak. Agar dapat mengikuti perkembangan zaman, sebuah sistem pendidikan harus memiliki kurikulum yang bersifat dinamis serta mengalami perubahan yang sistematis dan pengembangan yang berkelanjutan dan terarah (Syarif, 2004: 17). (Syaiful ,2017).

Tujuan dari penelitian ini adalah untuk menganalisis nilai karakter dalam pembelajaran tematik tema Cita-Citaku subtema Giat Berusaha Meraih Cita-Cita pada siswa kelas IV SD Negeri Lamper Tengah 02 Semarang.

Menurut Soegeng, (2015: 50) "nilai adalah sesuatu yang baik, yang berharga, yang berguna, yang menarik, yang diinginkan atau dicita-citakan setiap orang, bahkan diperjuangkan". Sedangkan karakter menurut Yaumi, (2014: 7) "karakter merupakan kulminasi dari kebiasaan yang dihasilkan dari pilihan etik, perilaku, dan sikap yang dimiliki individu yang merupakan moral yang prima walaupun ketika tidak seorang pun yang melihatnya". Berdasarkan pendapat di atas dapat disimpulkan bahwa nilai karakter adalah segala sesuatu yang bersifat baik yang mengajarkan tentang perilaku dan sikap yang akan menjadi acuan manusia untuk berkembang di kehidupannya.

Kadir dan Asrohah, (2014: 1) mengatakan pembelajaran tematik adalah program pembelajaran yang berangkat dari satu tema atau topik tertentu dan kemudian dielaborasi dari berbagai aspek atau ditinjau dari berbagai perspektif mata pelajaran yang biasa diajarkan di sekolah. Menurut Daryanto, (2014: 3) dengan pembelajaran tematik akan memperoleh beberapa keuntungan yaitu, sebagai berikut:

1) Siswa mudah memusatkan perhatian pada suatu tema tertentu.

2) Siswa mampu mempelajari pengetahuan dan mengembangkan berbagai kompetensi dasar antar mata pelajaran dalam tema yang sama. Pemahaman terhadap materi pelajaran lebih mendalam dan berkesan. Kompetensi dasar dapat dikembangkan lebih baik dengan mengaitkan mata pelajaran lain dengan pengalaman pribadi siswa. 
3) Siswa mampu lebih merasakan manfaat dan makna belajar karena materi disajikan dalam konteks tema yang jelas.

4) Siswa lebih bergairah belajar karena dapat berkomunikasi dalam situasi nyata untuk mengembangkan suatu kemampuan dalam satu mata pelajaran sekaligus mempelajari mata pelajaran lain.

5) Guru dapat menghemat waktu karena mata pelajaran yang disajikan dapat dipersiapkan sekaligus.

Tema Cita-citaku merupakan salah satu tema pembelajaran dalam buku tematik kurkulum 2013 di kelas IV Sekolah Dasar. Di dalam tema Cita-Citaku terdapat 3 subtema yaitu subtema Aku dan Cita-Citaku, Hebatnya Cita-Citaku, dan Giat Berusaha Meraih Cita-Cita. Tema Cita-Citaku mengaitkan beberapa mata pelajaran diantaranya IImu Pengetahuan Alam (IPA), Seni Budaya dan Prakarya (SBdP), Pendidikan Pancasila dan Kewarganegaraan (PPKn), Bahasa Indonesia, dan Ilmu Pengetahuan Sosial (IPS). Secara garis besar tema Cita-Citaku ini mempelajari tentang berbagai macam cita-cita, profesi, dan usaha yang dilakukan oleh seseorang untuk meraih cita-cita tertentu.

Pembelajaran adalah suatu proses yang dilaksanakan secara sistematik dimana setiap komponen saling berpengaruh. Pembelajaran merupakan seperangkat peristiwa yang memengaruhi terjadinya proses belajar mengajar. Pembelajaran adalah prosedur yang sistematik dalam mengorganisasikan pengalaman belajar untuk mencapai tujuan belajar tertentu. Dengan demikian, pembelajaran pada dasarnya merupakan kegiatan yang dilaksanakan secara terencanakan pada setiap tahapan yaitu perencanaan, pelaksanaan, dan penilaian pembelajaran serta pembelajaran tindak lanjut (Haling, 2012: 14-15). Guru sebagai pendidik profesional bertugas untuk mendidik, mengajar, membimbing, mengarahkan, melatih, menilai, dan mengevaluasi peserta didik pada pendidikan anak usia dini pada jalur pendidikan formal (Shabir, 2015). Pembelajaran tematik merupakan suatu konsep yang dapat dikatakan sebagai pendekatan pembelajaran yang melibatkan beberapa bidang studi untuk memberikan pengalaman yang bermakna kepada siswa. Bermakna artinya, siswa akan memahami konsepkonsep yang mereka pelajari itu melalui pengalaman langsung dan menghubungkannya dengan konsep lain yang sudah mereka pahami (Suko Pratomo: 6). Pembelajaran tematik dimaknai sebagai pembelajaran yang dirancang berdasarkan tema-tema tertentu. Dalam pembahasannya, tema itu ditinjau dari berbagai mata pelajaran (Trianto, 2011: 147). Pembelajaran tematik juga merupakan salah satu model dalam pembelajaran terpadu (integrated instruction) yang merupakan suatu sistem pembelajaran yang memungkinkan siswa, baik secara individual maupun kelompok, aktif menggali dan menemukan konsep serta prinsipprinsip keilmuan secara holistik, bermakna dan autentik (Rusman, 2012: 254)

Penggunaan model pembelajaran tematik berimplikasi pada proses penciptaan situasi belajar dan pembelajaran di mana siswa mempelajari beberapa mata pelajaran secara terpadu dalam satu tema pemersatu. Keterpaduan tersebut akan membuat konsep atau keterampilan yang ada dalam mata pelajaran menjadi lebih bermakna bagi siswa. Model pembelajaran tematik di sekolah dasar juga memberi peluang untuk membangun pengetahuan secara utuh, tidak terpecah-pecah dalam mata pelajaran (Hasrawati ,2016).

Menurut beberapa ahli pembelajaran model tematik (terpadu) dianggap sesuai dengan karakteristik perkembangan anak SD/MI. Siswa-siswi pada madrasah ibtidaiyah atau sekolah dasar pada kelas satu, dua, dan tiga termasuk pada rentangan usia dini yang seluruh aspek perkembangan kecerdasan (IQ, EQ, dan SQ) tumbuh dan berkembang sangat luar biasa, tergantung pada perkembangan siswa-siswi yang sesuai dengan kemampuan yang ada. Pada umumnya tingkat perkembangannya tersebut masih memandang bahwa segala sesuatu itu sebagai keutuhan (holistik) dan mampu memahami hubungan antara konsep secara sederhana dengan penerapan kehidupan sehari-hari. Proses pembelajarannya masih tergantung pada objek-objek kongkrit dan pengalaman yang dialami siswa-siswi secara langsung dan nyata untuk pengambilan pengalaman secara langsung.

Pembelajaran tematik adalah pembelajaran yang menggunakan tema dalam mengaitkan beberapa mata pelajaran sehingga dapat memberikan pengalaman bermakna kepada siswa. Tema adalah pokok pikiran atau gagasan pokok yang menjadi pokok pembicaraan. Dengan tema diharapkan akan memberikan banyak keuntungan, di antaranya: (1) siswa mudah memusatkan perhatian pada suatu tema tertentu; (2) siswa mampu mempelajari pengetahuan dan mengembangkan berbagai kompetensi dasar antar matapelajaran dalam tema yang sama; (3) pemahaman terhadap materi pelajaran lebih mendalam dan berkesan; (4) kompetensi dasar dapat dikembangkan lebih baik dengan mengkaitkan mata pelajaran lain dengan pengalaman pribadi siswa; (5) Siswa mampu lebih merasakan manfaat dan makna belajar karena materi 
disajikan dalam konteks tema yang jelas; (6) Siswa mampu lebih bergairah belajar karena dapat berkomunikasi dalam situasi nyata, untuk mengembangkan suatu kemampuan dalam satu mata pelajaran sekaligus mempelajari matapelajaran lain; (7) guru dapat menghemat waktu karena mata pelajaran yang disajikan secara tematik dapat dipersiapkaan sekaligus dan diberikan dalam dua atau tiga pertemuan, waktu selebihnya dapat digunakan untuk kegiatan remedial, pemantapan, atau pengayaan (Widyaningrum ,2012).

Pembelajaran tematik sebagai salah satu pendekatan integrasi secara alami menghubungkan fakta-fakta dan ide-ide dalam upaya untuk memahami dunia. Melalui jaringan tema, siswa dapat menghubungkan ide-ide dengan pengalaman dan lingkungan tempat tinggal siswa. Menyadari pentingnya terintegrasi dalam menyongsong kebutuhan belajar ramaja muda pada abad ke-21 dan mempersiapkan mereka untuk mengembangkan keterampilan berpikir tingkat tinggi yang diperlukan di era dunia semakin global (Davies, 2011). Siswa juga harus mempelajari keterampilan pentinguntuk sukses di dunia saat ini, seperti berpikir kritis, pemecahan masalah, komunikasi, dan kolaborasi (Partnership for 21 st Century Skill, 2009).Kelasyang menggabungkanketerampilanabad ke 21 untuk siswa SD tidak hanya mungkindilakukan di sekolah dasarsaat ini, tapi juga sangat penting untukdasarpembelajaranabad ke-21 (McKenna, 2011). Pembelajaran tematik memungkinkan siswa untuk mengembangkan ketrampilan berpikir tingkat tinggi (Ain ,2013).

\section{Metode}

Jenis penelitian ini adalah kualitatif dengan menggunakan pendekatan deskriptif kualitatif. Tempat penelitian ini dilaksanakan di SD Negeri Lamper Tengah 02 Semarang. Sumber data dalam penelitian ini adalah kepala sekolah, guru kelas, dan siswa kelas IV SD Negeri Lamper Tengah 02 Semarang. Teknik pengumpulan data yang digunakan dalam penelitian ini yaitu observasi, wawancara dan dokumentasi. Teknik keabsahan data menggunakan uji kredibilitas yaitu peningkatan ketekunan, triangulasi, dan menggunakan bahan referensi. Teknik analisis data dalam penelitian ini yaitu data reduction, data display dan conclusion drawing/verification.

\section{Hasil dan Pembahasan}

a. Nilai karakter Religius

Nilai karakter religius ditemukan ketika guru mengajak siswa berdoa sebelum pembelajaran dan sesudah pembelajaran serta memberikan kesempatan kepada siswa untuk melaksanakan ibadah.

b. Jujur

Nilai karakter jujur ditemukan ketika guru melarang siswa menyontek temannya ketika mengerjakan tugas.

c. Toleransi

Nilai karakter toleransi ditemukan ketika Guru memberikan pelayanan yang sama terhadap seluruh siswa tanpa membedakan agama dan status sosial serta memberikan kesempatan siswa untuk bekerja dengan kelompok yang berbeda.

d. Disiplin

Nilai karakter disiplin ditemukan ketika guru mengecek kehadiran siswa dan membiasakan siswa untuk mematuhi aturan serta membiasakan siswa untuk hadir tepat waktu.

e. Kerja Keras

Nilai karakter kerja keras ditemukan ketika guru menciptakan suasana belajar yang menumbuhkan sikap giat bekerja dan memotivasi siswa untuk belajar dengan sungguhsungguh.

f. Kreatif

Nilai karakter kreatif ditemukan ketika guru memberikan tugas yang memunculkan ide kreatifitas dan memberi kesempatan kepada siswa untuk berkarya.

g. Mandiri

Nilai karakter mandiri ditemukan ketika guru memberikan kesempatan kepada siswa untuk bekerja dan belajar mandiri.

h. Semangat Kebangsaan 
Nilai karakter semangat kebangsaan ditemukan ketika guru membagi siswa ke dalam kelompok agar bekerja sama dengan teman sekelas dan mendiskusikan hari-hari besar Nasional yaitu hari Kartini.

i. Cinta Tanah Air

Nilai karakter cinta tanah air ditemukan bahwa di kelas IV terdapat pajangan foto presiden dan wakilnya. Kemudian komunikasi antara guru dengan siswa menggunakan bahasa Indonesia serta menyanyikan lagu-lagu Nasional salah satunya adalah lagu Indonesia Raya yang di nyanyikan di kegiatan pendahuluan.

j. Bersahabat/Komunikatif

Nilai karakter bersahabat/ komunikatif ditemukan ketika guru mendengarkan keluhan seluruh siswa tanpa membeda-bedakan antara siswa satu dengan siswa lainnya dan tidak menjaga jarak dengan siswa serta menciptakan komunikasi yang dialogis.

k. Cinta Damai

Nilai karakter cinta damai ditemukan ketika guru menciptakan suasana kelas yang damai dan membiasakan perilaku anti kekerasan serta mengatur kelas tanpa membedakan antara siswa laki-laki dan siswa perempuan.

I. Peduli Lingkungan

Nilai karakter peduli lingkungan ditemukan ketika guru membiasakan siswa untuk menjaga kebersihan kelas dan membuang sampah pada tempatnya serta membuat jadwal piket kebersihan kelas.

m. Peduli Sosial

Nilai karakter peduli social ditemukan ketika guru menciptakan kerukunan warga kelas dan membiasakan siswa untuk saling menghormati sesama teman.

n. Tanggung Jawab

Nilai karakter tanggung jawab ditemukan ketika guru memeriksa pelaksanaan tugas piket kebersihan dan memberi tugas sesuai dengan waktu yang ditentukan.

Pendidikan karakter merupakan pendidikan yang digunakan untuk menunjang kurikulum 2013. Di dalam pendidikan karakter terdapat nilai-nilai karakter yang ditanamkan kepada diri siswa. Menurut Kesuma, (2012: 9) tujuan pertama pendidikan karakter adalah memfasilitasi penguatan dan pengembangan nilai-nilai tertentu sehingga terwujud dalam perilaku anak, baik ketika proses sekolah maupun setelah proses sekolah. pendidikan budaya dan karakter bangsa dipandang sebagai solusi cerdas untuk menghasilkan peserta didik yang memiliki kepribadian unggul, berakhlak mulia, dan menunjang tinggi nilai-nilai keindonesiaan secara menyeluruh (Yaumi, 2014: 120). Hal tersebut sejalan dengan pendapat Putri, (2018: 72) yang mengatakan pembangunan karakter masyarakat Indonesia yang berakhlak mulia, bermoral, beretika, berbudaya, dan beradab juga menjadi bagian penting guna tercapainya Indonesia yang maju, mandiri, dan adil.

Upaya pengembangan nilai-nilai karakter kepada diri siswa harus ditanamkan sedini mungkin. Salah satu upaya untuk menanamkan nilai-nilai karakter kepada siswa adalah melalui kegiatan pembelajaran khususnya dalam pembelajaran tematik. Pembelajaran tematik merupakan pembelajaran yang mengaitkan dua atau lebih mata pelajaran menjadi satu tema. Melalui pembelajaran tematik maka dapat diterapkan nilai-nilai karakter kepada siswa. Hal tersebut sesuai dengan pendapat Ghufron dalam Zubaedi, (2011: 263-264) yang mengatakan bahwa pengintegrasian nilai-nilai karakter ke dalam kegiatan pembelajaran berarti memadukan, memasukkan, dan menerapkan nilai-nilai yang diyakini baik dan benar dalam rangka membentuk, mengembangkan, dan membina tabiat atau kepribadian peserta didik sesuai jati diri bangsa tatkala kegiatan pembelajaran berlangsung.

Berdasarkan hasil penelitian, di dalam pembelajaran tematik tema Cita-Citaku yang berpedoman pada instrumen yang telah dibuat oleh peneliti sebagai alat untuk mendapatkan data penelitian, sudah terdapat nilai-nilai karakter untuk mencapai tujuan pendidikan. Berdasarkan hasil observasi, ternyata dalam pembelajaran tematik subtema Giat Berusaha Meraih Cita-Cita kelas IV terdapat 14 nilai karakter yang ditemukan yaitu religius, jujur, toleransi, disiplin, kerja keras, kreatif, mandiri, semangat kebangsaan, cinta tanah air, bersahabat/komunikatif, cinta damai, peduli lingkungan, peduli sosial, dan tanggung jawab. Nilai tersebut sesuai dengan nilai-nilai pendidikan karakter oleh Kemendiknas yang perlu diinternalisasikan pada anak yaitu religius, jujur, toleransi, disiplin, kerja keras, kreatif, mandiri, 
demokratis, rasa ingin tahu, semangat kebangsaan, cinta tanah air, menghargai prestasi, bersahabat dan komunikatif, cinta damai, gemar membaca, peduli lingkungan, peduli sosial, dan tanggung jawab (Wibowo, 2012: 71-73). Nilai karakter yang tidak muncul yaitu Menghargai Prestasi, Demokratis, Rasa Ingin Tahu, dan Gemar Membaca.

\section{Simpulan dan Saran}

Berdasarkan hasil penelitian dan analisis dalam pembahasan yang telah diuraikan oleh peneliti, dalam pembelajaran tematik tema Cita-Citaku subtema Giat Berusaha Meraih Cita-Cita maka dapat disimpulkan bahwa mengacu pada 18 nilai karakter yang dikeluarkan oleh kemendikbud, secara keseluruhan terdapat 14 nilai karakter yang muncul dari 18 nilai karakter yang diamati dalam kegiatan pembelajaran. Nilai karakter tersebut antara lain: (1) Religius, (2) Jujur, (3) Toleransi, (4) Disiplin, (5) Kerja Keras, (6) Kreatif, (7) Mandiri, (8) Semangat Kebangsaan, (9) Cinta Tanah Air, (10) Bersahabat/ Komunikatif, (11) Cinta Damai, (12) Peduli Lingkungan, (13) Peduli Sosial, dan (14) Tanggung Jawab. Sedangkan nilai karakter yang tidak muncul dalam pembelajaran tematik subtema Giat Berusaha Meraih Cita-Cita terdapat 4 nilai karakter. Ke empat nilai karakter tersebut adalah (1) Demokratis, (2) Rasa Ingin Tahu, (3) Menghargai Prestasi, dan (4) Gemar Membaca. Penerapan nilai karakter pada saat kegiatan pembelajaran berlangsung sangat penting, karena dapat membentuk karakter, watak, dan sikap siswa untuk modal dalam berkembang dan berlangsungnya kehidupan siswa baik itu di lingkungan sekolah dan lingkungan masyarakat serta menyiapkan mental untuk menghadapi tantangan di masa yang akan datang.

\section{Daftar Pustaka}

Ain ,Nurul (2013). Implementasi Kurikulum KTSP: Pembelajaran Tematik Di Sekolah Dasar . Jurnal Inspirasi Pendidikan Universitas Kanjuruhan Malang

Daryanto. 2014. Pembelajaran Tematik, Terpadu, Terintegrasi (Kurikulum 2013). Yogyakarta: Gava Media.

Hasrawati (2016). Perangkat Pembelajaran Tematik Di Sd The Learning Media Of Tematik In Primary School . Jurnal Pendidikan Dasar Islam Vol. 3 No. 1, June 2016

Gumilang, A. (28 Febuari 2018). Tawuran Pelajar di Banyumanik Satu Luka-luka dan 15 Siswa Ditangkap Polisi. Tribunjateng.com. retrieved from http://jateng.tribunnews.com.

Kadir \& Asrohah. 2014. Pembelajaran Tematik. Jakarta: PT Raja Grafindo Persada.

Kesuma, D., dkk. 2012. Pendidikan Karakter. Bandung: PT Remaja Rosdakarya.

Noor, R.M. 2012. Mengembangkan Karakter Anak Secara Efektif di Sekolah dan di Rumah. Yogyakarta: Pedagogia.

Nurkholis (2013). Pendidikan Dalam Upaya Memajukan Teknologi . Jurnal Kependidikan, Vol. 1 No. 1 Nopember 2013

Palupi ,Dini (2018). Pendidikan Karakter Pada Anak Sekolah Dasar di Era Digital . Jurnal Pendidikan Dasar vol. 2, no. 1, 2018

Putri, A.D.S. 2018. "Keefektifan Modul Pembelajaran Menulis Karangan Berbasis Pendidikan Karakter pada Peserta Didik Kelas IV Seolah Dasar". Jurnal Pendidikan Dasar. Vol 6, No 2, Hal 72-76.

Soegeng, A.Y. 2015. Etika Pancasila. Yogyakarta: Magnum Pustaka Utama.

Soegeng, A.Y. 2018. Filsafat Pendidikan. Yogyakarta: Magnum Pustaka Utama.

Syaiful ,Islam (2017). Karakteristik Pendidikan Karakter; Menjawab Tantangan Multidimensional Melalui Implementasi Kurikulum 2013 . Jurnal Institut Agama Islam Nurul Jadid Paiton Probolinggo Vol. 01 No. 01 Tahun 2017 
IVCEJ, Vol 2 No 1, Tahun 2019

p-ISSN: 2615-4684 e-ISSN: 2615-6938

Wibowo, A. 2012. Pendidikan Karakter Usia Dini (Strategi Membangun Karakter Di Usia Emas). Yogyakarta: Pustaka Pelajar.

Widyaningrum ,Retno (2012). Model Pembelajaran Tematik Di Mi/Sd . Jurnal Cendekia Vol. 10 No. 1 Juni 2012

Yaumi, M. 2014. Pendidikan Karakter. Jakarta: Prenada Media Group.

Zubaedi. 2011. Desain Pendidikan Karakter. Jakarta: Prenada Media Group. 